\title{
Identification and characterization of ostreid herpesvirus 1 associated with massive mortalities of Scapharca broughtonii broodstocks in China
}

\author{
Changming Bai ${ }^{1,2}$, Wenhui Gao ${ }^{1}$, Chongming Wang ${ }^{1,2, *}$, Tao $\mathrm{Yu}^{3}$, Tianwen Zhang ${ }^{4}$, \\ Zhaoxing Qiu ${ }^{4}$, Qingchen Wang ${ }^{1}$, Jie Huang ${ }^{1,2}$
}
${ }^{1}$ Division of Maricultural Organism Disease Control and Molecular Pathology, Yellow Sea Fisheries Research Institute, Chinese Academy of Fishery Sciences, 106 Nanjing Road, Qingdao 266071, PR China
${ }^{2}$ Laboratory for Marine Fisheries and Aquaculture, Qingdao National Laboratory for Marine Science and Technology, 1 Wenhai Road, Aoshanwei town, Qingdao 266237, PR China
${ }^{3}$ Changdao Enhancement and Experiment Station, Chinese Academy of Fishery Sciences, 2 Haibin Road, Changdao county, Yantai 265899, PR China

${ }^{4}$ Benthic Biology Research Centre, Marine Biology Institute of Shandong Province, 7 Youyun Road, Qingdao 266104, PR China

\begin{abstract}
In the early summer of 2012 and 2013, mass mortalities of blood ark shell (Scapharca [Anadara] broughtonii), broodstocks were reported in several hatcheries on the coast of northern China. Clinical signs including slow response, gaping valves and pale visceral mass were observed in diseased individuals. In response to these reported mortalities, 238 samples were collected from hatcheries at 6 sites. Microscopic changes including lysed connective tissue, dilation of the digestive tubules, eosinophilic inclusion bodies, nuclear chromatin margination and pyknosis were found in affected animals. Transmission electron microscopy (TEM) revealed herpes-like viral particles within the connective tissue of the mantle. Quantative PCR (qPCR) and nested PCR (nPCR) analysis using primers specific for ostreid herpesvirus 1 (OsHV-1) indicated significant higher prevalence of OsHV-1 DNA in cases associated with mass mortalities than those without mass mortalities ( $p=0.0012$ for $\mathrm{qPCR}, \mathrm{p}<0.0001$ for $\mathrm{nPCR}$ ). $\mathrm{qPCR}$ also indicated that samples associated with mass mortalities carried high viral DNA loads, while the loads in apparently healthy samples were significantly lower $(t=3.15, \mathrm{df}=92, \mathrm{p}=0.002)$. Sequence analysis of the $\mathrm{C} 2 / \mathrm{C} 6$ region of $\mathrm{nPCR}$ products revealed 5 newly described variants, which were closely related to each other. Phylogenetic analysis of the 5 virus variants and 48 virus variants reported in previous studies identified 2 main phylogenetic groups, and the 5 virus variants identified here were allocated to a separate subclade. To our knowledge, this is the first report of mass mortalities of bivalve broodstocks associated with OsHV-1 infection.
\end{abstract}

KEY WORDS: Scapharca broughtonii · Herpes-like virus · Ostreid herpesvirus 1 - Mass mortality · Aquaculture Resale or republication not permitted without written consent of the publisher

\section{INTRODUCTION}

Scapharca broughtonii, a member of the family Arcidae and the genus Scapharca, is distributed widely along the coasts of northern China, the Russian Far East, South Korea, and Japan (An \& Park
2005, Sugiura et al. 2014). Frequent and intensive fishing caused an extreme decline in the production of $S$. broughtonii after the early 1990s in China (Tang et al. 1994). To eliminate hunting pressure on the wild $S$. broughtonii population, artificial techniques for mass production of $S$. broughtonii seeds 
were developed (Wang \& Li 1986). Additionally, in order to promote stock restoration, S. broughtonii broodstocks introduced from South Korea to China have been used for hatchery propagation and seed release in recent years (Liang et al. 2011). During 2011 to 2013, about 700 million seeds with shell lengths of 10-15 mm were released to the wild each year in Shandong Province (Z. Qiu unpubl. data). With the expansion of the $S$. broughtonii aquaculture industry, mass mortalities of $S$. broughtonii have been reported in China (Zhang \& Wang 1994). Several studies, which focused mainly on environmental factors, have been carried out to investigate the cause of these mortalities (Li 1996, Wang \& Sui 1996). The role of herpes-like viruses, one of the most common viral etiologies in bivalves around the world, has never been investigated in $S$. broughtonii mortality events.

Herpes-like viral infections were firstly described in Crassostrea virginica adults in 1972 from the east coast of the USA (Farley et al. 1972). Further mortality outbreaks associated with the detection of herpeslike viruses have been reported from different bivalve species, including various species of oyster, clam, scallop and abalone in China and other countries throughout the world (Hine et al. 1992, 1998, Renault et al. 2001, Wang et al. 2002, Chang et al. 2005, Tan et al. 2008, Ren et al. 2013). Mortality outbreaks associated with ostreid herpes-like viruses were usually reported in larvae and spat during the summer period of each year (Renault et al. 1994a, 2000, Arzul et al. 2002). Viral particles isolated from infected $C$. gigas larvae have been fully characterized on both a morphological and molecular basis (Le Deuff \& Renault 1999, Davison et al. 2005) and named ostreid herpesvirus 1 (Minson et al. 2000, Arzul et al. 2002). Genome sequencing and comparison showed ostreid herpesvirus 1 is tenuously related to the 2 classes of vertebrate herpesviruses and represents a novel major class of herpesviruses (Davison et al. 2005). Ostreid herpesvirus 1 was subsequently assigned as the founding member of the species Ostreid herpesvirus 1 (OsHV-1), genus Ostreavirus, family Malacoherpesviridae and order Herpesvirales (Davison et al. 2009).

Mass mortalities of bivalves associated with herpes-like virus in China were firstly reported in Zhikong scallops Chlamys farreri in the late 1990s (Song et al. 2001, Wang et al. 2002), and the herpeslike virus was initially named the acute viral necrosis virus (AVNV) (Song et al. 2001, Wang et al. 2002). The completion of genome sequence and genetic comparison of OsHV-1 and AVNV revealed that they are 2 variants of the same virus (Renault et al. 2012, Ren et al. 2013). Recently, OsHV-1 was also detected in farmed C. gigas in the other 2 Asian countries (Japan and South Korea) and associated with mass mortalities of larvae in artificial hatcheries in South Korea (Shimahara et al. 2012, Hwang et al. 2013, Jee et al. 2013).

In the early summer of 2012 and 2013, mass mortalities of $S$. broughtonii were reported among batches indigenous to China and those introduced from South Korea. Given the clinical signs and mortality trends and patterns observed in these events, a disease was suspected to be responsible for the outbreaks of these mass mortalities. Samples collected from these hatcheries and the surrounding open sea areas were analyzed for the presence of OsHV-1.

\section{MATERIALS AND METHODS}

\section{Scapharca broughtonii introduction and sampling}

S. broughtonii broodstocks introduced from South Korea (caught from the wild) were firstly cultivated in pearl nets in the open sea at Site ChangD (see Fig. 1) for at least 2 wk to ease the stress of transportation, and then they were transferred to the hatcheries for further production. Local populations of $S$. broughtonii broodstocks in China were transferred to the hatcheries directly after they were caught in the wild. The water temperatures in the wild were about $10^{\circ} \mathrm{C}$ and $7^{\circ} \mathrm{C}$ in 2012 and 2013 , respectively, when the broodstocks were transferred to the hatcheries. The water temperature at the hatchery was kept the same as it was in the wild for the first week after the broodstocks were transferred in, and then they were slowly acclimated at a speed of $1^{\circ} \mathrm{C} \mathrm{d}^{-1}$ to $18^{\circ} \mathrm{C}$, the temperature at which the mass mortalities occured.

Samples of S. broughtonii were taken in June 2012 and during March to July 2013, which was the prime time of mortalities incidences reported by owners of bivalve hatcheries and related organizations. Additionally, S. broughtonii juveniles with 5 different sizes (see Table 1) cultivated in the open sea near an affected hatchery at site RiZ were also sampled in May 2013 (about $9^{\circ} \mathrm{C}$ when sampled). Collected samples were conserved in an ice box and transferred to the laboratory immediately. Upon receipt, each $S$. broughtonii was opened and examined for any signs of abnormality, including shrunken mantle, abnormal coloration, lesions, presence of abscesses and tissue discoloration, etc. 


\section{Histopathology}

For histopathological examination, gills, mantles and digestive glands dissected from 2 diseased $S$. broughtonii were fixed in Davidson's alcohol, formalin, acetic acid (AFA) fixative for $24 \mathrm{~h}$ and then transferred to $70 \%$ alcohol for storage. The histological sections were made according to standard protocols including dehydration in ethanol series, clearing, embedding in paraffin and cutting into $5 \mu \mathrm{m}$ thick sections using a Leica microtome RM2145 (Leica Instruments). The sections were then stained with hematoxylin and eosin (H\&E) for standard histopathological evaluation using a light microscope (Nikon Eclipse 80i). In order to compare these with the tissue architecture of normal organs of $S$. broughtonii, tissues collected from one apparently healthy individual were also handled with the same procedure as described above.

\section{Transmission electron microscopy (TEM) examination}

For TEM examination, tissues dissected from the same organs as those used for histological examination were fixed directly in cold $2.5 \%$ glutaraldehyde ( $\mathrm{pH} 7.2$ ) in $0.2 \mathrm{M}$ sodium cacodylate, post-fixed in $1 \%$ osmium tetroxide in the same buffer and dehydrated in ethanol series. Then the tissues were embedded in Epon812 and cut on a Ultracut-E ultramicrotome, stained with uranyl acetate and lead citrate, and examined with a JEOL JEM-1200EX at $80 \mathrm{kV}$ at the Medical College of Qingdao University.

\section{Nucleic acid extraction}

Mantle fragments in $30 \mathrm{mg}$ from each individual of all 238 samples (10 batches) were dissected for DNA extraction, which was carried out with a TIANamp ${ }^{\mathrm{TM}}$ Marine Animals DNA Kit (Tiangen Biotech) according to the manufacturer's handbook. The extracted nucleic acid were then stored at $-40^{\circ} \mathrm{C}$ until the time of testing. Extraction blank controls were included in the extraction process to detect cross-contamination between samples.

\section{Polymerase chain reaction detection}

Molecular detections of OsHV-1 DNA were undertaken using both nested PCR (nPCR) and quantita- tive PCR (qPCR). The qPCR was adapted from a previously published protocol (Martenot et al. 2010). Briefly, amplification was performed in $25 \mu \mathrm{l}$ reactions containing $12.5 \mu$ l of 2 FastStart Essential DNA Probes Master (Roche Diagnostics), $0.5 \mu$ of each primer $(20 \mu \mathrm{M}), 0.5 \mu \mathrm{l}$ of $\operatorname{TaqMan}^{\circledR}$ probes $(10 \mu \mathrm{M})$, $2 \mu \mathrm{l}$ of template DNA and $9 \mu \mathrm{l}$ water. The PCR assay was performed using Bio-Rad CFX Connect RealTime system (Bio-Rad Laboratories) and run under the following conditions: 1 cycle $95^{\circ} \mathrm{C}$ for $10 \mathrm{~min}$, followed by 40 cycles of amplification at $95^{\circ} \mathrm{C}$ for $10 \mathrm{~s}$, $60^{\circ} \mathrm{C}$ for $30 \mathrm{~s}$. The virus quantitation was carried out by comparison with a standard curve, which was created from a 10 -fold dilution series $\left(10^{7}-10^{1}\right.$ copies $\mathrm{ll}^{-1}$ ) of plasmid containing the target sequence. A negative control was carried out with $2 \mu$ of deionised water. Each sample was tested in duplicate and the sample was recorded as positive if both replicates were amplified and indicated the presence of OsHV-1 DNA. We estimated the OsHV-1 infection burdens as the mean genomic equivalent (GE) score $\mathrm{mg}^{-1}$ of tissue for the 2 replicates.

The nPCR employed here was developed in-house with the purpose of improving the sensitivity of the common PCR assay. A pair of primers targeting an approximately $1100 \mathrm{bp}$ fragment in the $\mathrm{C}$ region of the OsHV-1 genome were selected for the first amplification step of the nPCR: the forward primer was named CFor (5'-ATT ACC CAG ATT CCC CTC-3') and was located at the region flanking open reading frame 4 (ORF 4); the reverse primer was named CRev (5'-CCA CGA ATG TAA ACT GTG AC-3') and was located in the middle region of ORF 4 . We amplified the targeting DNA fragment using CFor/CRev for the first PCR step. We then amplified the first-round PCR products using primer pair C2/C6 (Renault \& Arzul 2001), which could generate fragments about 700 bp. Special care was taken to prevent false positive results due to contamination, i.e. frequent changes of disposable gloves and preparation of pre- and postPCR materials in separate locations.

Our initial PCR procedure was optimized to achieve a detection sensitivity of as little as 10 copies of genomic DNA per $\mu$ lC. X. Yang et al. unpubl. data). The final protocol was carried on with $1 \mu \mathrm{l}$ of each template DNA in a $24 \mu \mathrm{l}$ reaction pre-mixture, containing $2 \times$ PCR buffer (20 mM Tris-HCl, $100 \mathrm{mM}$

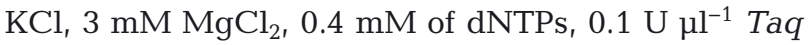
DNA polymerase and PCR enhancer) (Dongsheng Biotech) and $0.4 \mathrm{mM}$ of each primer. The conditions for the first amplification included an initial denaturation for $5 \mathrm{~min}$ at $94^{\circ} \mathrm{C} ; 35$ cycles of $30 \mathrm{~s}$ at $94^{\circ} \mathrm{C}, 30 \mathrm{~s}$ at $52.5^{\circ} \mathrm{C}$ and $1 \mathrm{~min}$ at $72^{\circ} \mathrm{C}$; and a final extension for 
5 min at $72^{\circ} \mathrm{C}$. The conditions for the second amplification were an initial denaturation for $5 \mathrm{~min}$ at $94^{\circ} \mathrm{C}_{\text {; }}$ 25 cycles of $30 \mathrm{~s}$ at $94^{\circ} \mathrm{C}, 45 \mathrm{~s}$ at $50^{\circ} \mathrm{C}$ and $30 \mathrm{~s}$ at $72^{\circ} \mathrm{C}_{\text {; }}$ and a final extension for $5 \mathrm{~min}$ at $72^{\circ} \mathrm{C}$. Sterilized distilled water and 10 copies $\mathrm{\mu l}^{-1}$ plasmid DNA containing cloned target sequences were used as negative and positive controls.

The PCR products (approximately $700 \mathrm{bp}$ ) were then separated by agarose gel electrophoresis $(1.5 \%$ agarose gels). Finally, PCR products of the positive samples were directly sequenced using primers $\mathrm{C} 2$ and C6 (Sangon Biological Engineering Technology \& Service Company). For batches where less than 20 positive samples were detected, all PCR products were sequenced. For batches where more than 20 positives samples were detected, only some PCR products (but no less than 10) were selected randomly and sequenced.

\section{Phylogenetic analysis}

Sequences were aligned with MAFFT version 7 with the default settings (Katoh et al. 2002, Katoh \& Standley 2013), followed by manual adjustments with BioEdit 7.0.0 (Hall 1999). The number of virus variants was calculated with DnaSP 5.10 (Rozas et al. 2003). To compare the phylogenetic relationship between virus variants identified in this study and those reported in other countries, 48 virus variants identified in previous studies were included in the dataset (Table S1 in the Supplement; www.int-res.com/ articles/suppl/d118p065_supp.pdf) (Shimahara et al. 2012). Aligned gaps were coded as binary data (sequence present $=1$, sequence absent $=0$ ) by the program GapCoder applying the single indel coding method described by Simmons \& Ochoterena (2000) and Young \& Healy (2003).

\section{RESULTS}

\section{Field observations}

Scapharca broughtonii broodstocks cultivated in 2 hatcheries, i.e. in LaiZ and ChangD, Shandong Province, China, experienced $>75 \%$ mortalities in June 2012. Moribund individuals showed clinical signs including slow response, gaping valves and pale visceral mass. Recurrent mass mortalities of $S$. broughtonii broodstocks were observed again in more hatcheries in China (Shandong and Liaoning Province) in April 2013 (Fig. 1). Additional cases of

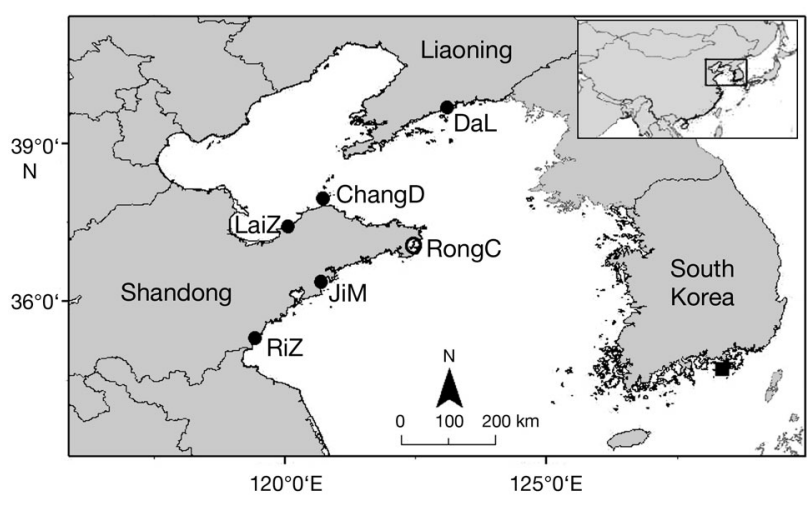

Fig. 1. Scapharca broughtonii sampling sites, where OsHV1 was detected $(\bullet)$ or not detected $(0)$. Site in South Korea (匹) from which $S$. broughtonii broodstocks were introduced (to China)

mass mortalities were reported in 2012 ( 2 cases) and 2013 (4 cases). Mass mortalities broke out when the water temperature reached $18^{\circ} \mathrm{C}$ in the hatcheries and lasted about $1 \mathrm{wk}$, while no mass mortality was found in $S$. broughtonii populations cultivated in the open sea near the hatcheries.

\section{Histopathology}

Two $S$. broughtonii confirmed positive for OsHV-1 DNA detected by PCR and 1 healthy $S$. broughtonii were examined by histology. The normal un-infected digestive gland of $S$. broughtonii consists of digestive tubules with various degrees of vacuolization (Fig. 2A). In OsHV-1 PCR positive clams, morphological changes including tubule dilation and lysed connective tissue were observed throughout the sections (Fig. 2B). Eosinophilic inclusion bodies (Fig. 2C) and abnormally shaped nuclei (chromatin margination and pyknosis, Fig. 2D) were also frequently observed in the digestive gland of OsHV-1 PCR positive $S$. broughtonii.

\section{Observation of viral particles by TEM}

TEM revealed herpes-like virus particles in the mantle of moribund S. broughtonii (Fig. 3) but not in any tissue of uninfected $S$. broughtonii. Both intranuclear empty capsids and nucleocapsids (Fig. 3A,B) measuring $109.92 \pm 1.55 \mathrm{~nm}( \pm \mathrm{SE})$ in diameter were observed within the nucleus of infected cells in the connective tissues of the mantle. Enveloped extracellular viral particles (Fig. 3C,D) measuring $151.16 \pm$ $1.24 \mathrm{~nm}( \pm \mathrm{SE})$ were frequently visualized in the 

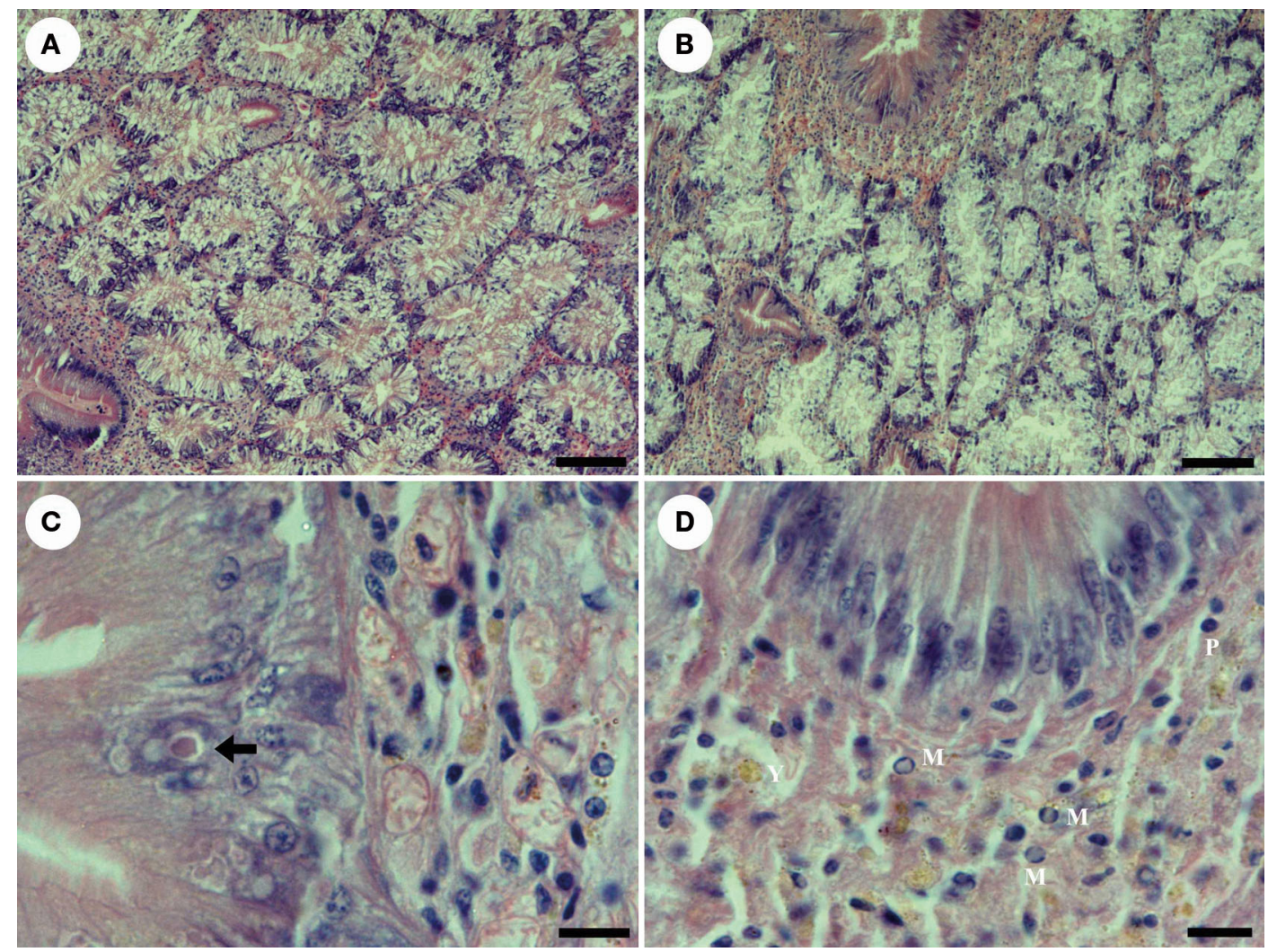

Fig. 2. Photomicrographs of digestive gland and cellular architecture of Scapharca broughtonii. (A) Various degrees of vacuolization observed in normal digestive tubules of a $S$. broughtonii tested negative for OsHV-1 DNA by PCR (scale bar = $100 \mu \mathrm{m}$ ). (B) Lysed connective tissue and tubule dilation observed in a $S$. broughtonii collected during a mortality event (scale bar $=100 \mu \mathrm{m})$. (C) Inclusion bodies (arrow) in the digestive tubule epithelium of infected $S$. broughtonii (scale bar $=10 \mu \mathrm{m})$. (D) Abnormal nuclear features in in the digestive gland of a $S$. broughtonii infected with OsHV-1. M: nuclear margination;

P: pycnosis; Y: yellowish material typically associated with OsHV-1 infection (scale bar $=10 \mu \mathrm{m})$

intercellular space under the epithelial cells. Additionally, capsids with pleomorphic cores were also usually found near the chromatin, which may be interpreted as the process of acquisition of nucleoid into capsids (Fig. 3A,B) as reported by Hine \& Thorne (1997) and Renault et al. (2000).

\section{Molecular detection of OsHV-1}

Out of 238 samples, 133 (55.9\%) tested positive for OsHV-1 DNA detection by nPCR assay (Table 1). All samples that were positive by nPCR were also positive by the qPCR assay, while 32 negative samples tested by nPCR were proved positive by qPCR assay. Of the 32 samples, 2 were associated with mass mortalities (GEs $=4.73 \times 10^{4}$ and $1.27 \times 10^{3}$ ), 30 were apparently healthy (GEs ranged from 6.03 to 420.00 , mean $=128.29$, median $=61.70)$. Both $\mathrm{qPCR}$ and nPCR assay indicated higher prevalence of OsHV-1
DNA detection in cases with mass mortalities (93/94 $=98.9 \%$ for $\mathrm{qPCR}$ and $91 / 94=96.8 \%$ for $\mathrm{nPCR}$ ) than those without mass mortalities $(72 / 144=50.0 \%$ for $\mathrm{qPCR}$ and $42 / 144=29.2 \%$ for $\mathrm{nPCR})\left(\chi^{2}=10.48\right.$, $\mathrm{df}=1, \mathrm{p}=0.0012$ for $\mathrm{qPCR}$ and $\chi^{2}=27.41, \mathrm{df}=1, \mathrm{p}<$ 0.0001 for $\mathrm{nPCR}$ ). qPCR also indicated that mean GEs for samples associated with mass mortalities (GE mean $=2.22 \times 10^{7}, \mathrm{SE}=7.04 \times 10^{6}, \mathrm{n}=93$ ) were significantly higher than those (GE mean $=296.28, \mathrm{SE}=$ 64.90, $\mathrm{n}=72)$ without mass mortalities $(t=3.15, \mathrm{df}=$ $92, \mathrm{p}=0.002$ ). Of the 6 cases of mass mortalities, mean GEs of 3 of them were over $10^{6}$, one of them was near $10^{4}$ and the other 2 were less than $10^{3}$. The mean GEs for all 12 batches with apparently healthy samples ranged from 4.60 to 807.26 (median = 207.33). A high percentage of OsHV-1 DNA was also detected in juveniles with moderate viral loads (which varied from 162.00 to 807.26 GEs, mean = 440.17), and no abnormal mortalities were found among them. 


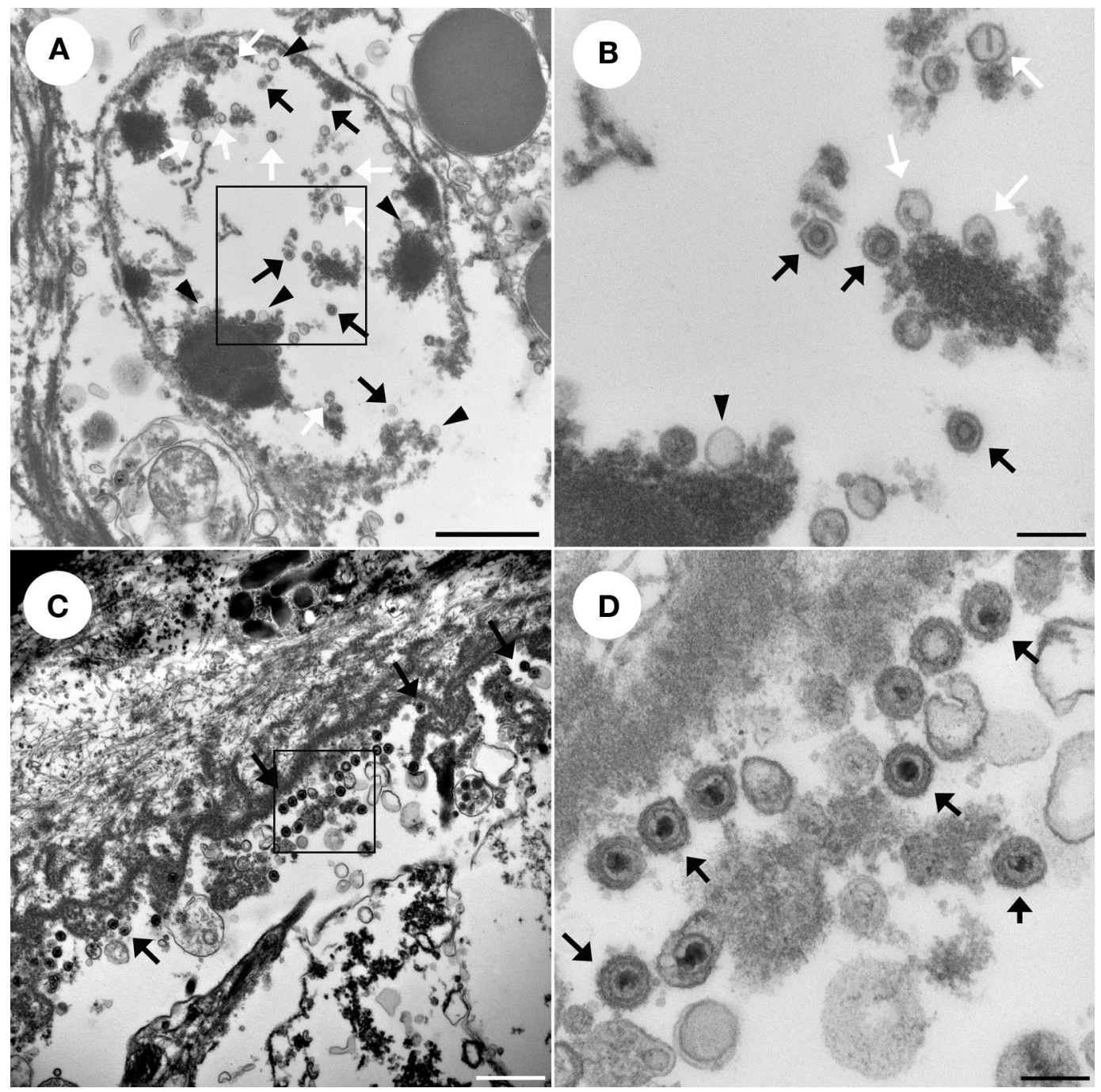

Fig. 3. Herpes-like virus observed in the mantle of infected Scapharca broughtonii. (A) Intra-nuclear nucleocapsids (black arrows), empty capsids (arrowheads) and capsids with pleomorphic cores (white arrows) detected in the nuclei of infected cell (scale bar $=1 \mu \mathrm{m})$. (B) High magnification graphic of the region indicated by the box in panel $(\mathrm{A})(\mathrm{scale} b a r=200 \mathrm{~nm})$. $(\mathrm{C})$ Enveloped extracellular virus particles (arrows) observed in the intracellular space under the epithelial cells (scale bar = $1 \mu \mathrm{m})$.

(D) High magnification graphic of the region indicated by the box in panel (C) (scale bar = $200 \mathrm{~nm}$ )

\section{Genetic variation of OsHV-1}

Of the 133 positive samples, PCR amplicons of 84 representative samples were sequenced (Table 1). The analysis of these sequences revealed 5 virus variants, which varied from 585 to $593 \mathrm{bp}$ in length. The virus variants were represented as CN1 to CN5 in this study and registered in GenBank with the accession numbers KR075679-KR075683. All of these virus variants were shared by local populations of $S$. broughtonii in China and those introduced from South Korea. The total length was 614 bp after alignment as a result of variation of repeat numbers of the microsatellite locus. Genetic variation was only found in 2 loci with insertion/deletion polymorphism. The main polymorphism was found in a microsatellite region that was characterized by ACT repeats. Compared to $8 \mathrm{ACT}$ repeats in the reference sequence (AY509253), there were 6, 7, 8 and 9 ACT repeats found in $\mathrm{CN} 4, \mathrm{CN} 2$ and $\mathrm{CN} 3, \mathrm{CN} 5$ and $\mathrm{CN} 1$, respectively. Another polymorphism locus was characterized by a deletion of $\mathrm{G}$ in $\mathrm{CN} 1$ and $\mathrm{CN} 2$ compared the other 3 virus variants. Of the 84 sequences, $57(67.9 \%)$ belonged to the virus variant CN3, followed by CN2 (15 sequences), CN1 (6 sequences), CN4 (5 sequences) and CN5 (1 sequences) (Table 1). 
Table 1. Prevalence, average genomic equivalents (GE) and variants of OsHV-1 in Scapharca broughtonii cultivated in China. qPCR: quantitative PCR; nPCR: nested PCR

\begin{tabular}{|c|c|c|c|c|c|c|c|}
\hline Site & $\begin{array}{l}\text { Date of } \\
\text { sampling }\end{array}$ & $\begin{array}{c}\text { Development } \\
\text { stage } \\
\text { (shell height, mm) }\end{array}$ & $\begin{array}{c}\text { No. of } \\
\text { samples }\end{array}$ & $\begin{array}{c}\text { Mean } \\
\mathrm{GE} \pm \mathrm{SE}\end{array}$ & $\begin{array}{r}\text { Prevalence } \\
\text { of qPCR assay }\end{array}$ & $\begin{array}{l}(\%)(95 \% \mathrm{CI}) \\
\text { of nPCR assay }\end{array}$ & $\begin{array}{c}\text { Variant } \\
\text { (no. of infected } \\
\text { mollusks) }\end{array}$ \\
\hline ChangD $^{\mathrm{a}}$ & $\begin{array}{l}\text { Jun } 2012^{\mathrm{b}} \\
\text { Mar } 2013 \\
\text { Apr } 2013^{\mathrm{b}, \mathrm{c}} \\
\text { May } 2013 \\
\text { Jul } 2013\end{array}$ & $\begin{array}{l}\text { Adult } \\
\text { Adult } \\
\text { Adult } \\
\text { Adult } \\
\text { Adult }\end{array}$ & $\begin{array}{r}15 \\
4 \\
27 \\
30 \\
20\end{array}$ & $\begin{aligned} 2.58 \times 10^{7} & \pm 2.30 \times 10^{7} \\
252.67 & \pm 252.67 \\
1.11 \times 10^{7} & \pm 2.71 \times 10^{6} \\
31.84 & \pm 5.37 \\
4.60 & \pm 4.60\end{aligned}$ & $\begin{aligned} 100 & (75-100) \\
25 & (1-78) \\
100 & (85-100) \\
63 & (44-79) \\
5 & (0-27)\end{aligned}$ & $\begin{aligned} 93 & (66-100) \\
25 & (1-78) \\
100 & (85-100) \\
30 & (15-50) \\
5 & (0-27)\end{aligned}$ & $\begin{array}{c}\text { CN2 (10), CN4 (4) } \\
\text { CN5 (1) } \\
\text { CN1 (4), CN3 (9) } \\
\text { CN1 (2), CN3 (7) } \\
\text { CN3 (1) }\end{array}$ \\
\hline LaiZ & Jun $2012^{\mathrm{b}}$ & Adult & 6 & $345.83 \pm 172.48$ & $100(52-100)$ & $100(52-100)$ & CN2 (5), CN4 (1) \\
\hline JiM & $\begin{array}{l}\text { Apr } 2013^{b, c} \\
\text { May } 2013\end{array}$ & $\begin{array}{l}\text { Adult } \\
\text { Adult }\end{array}$ & $\begin{array}{r}30 \\
5\end{array}$ & $\begin{array}{c}4.58 \times 10^{7} \pm 1.79 \times 10^{7} \\
0\end{array}$ & $\begin{array}{c}100(86-100) \\
0(0-54)\end{array}$ & $\begin{array}{c}97(81-100) \\
0(0-54)\end{array}$ & CN3 (10) \\
\hline DaL & $\begin{array}{l}\text { Apr } 2013^{b, c} \\
\text { May } 2013\end{array}$ & $\begin{array}{l}\text { Adult } \\
\text { Adult }\end{array}$ & $\begin{array}{r}13 \\
5\end{array}$ & $\begin{array}{l}38.16 \pm 10.86 \\
17.00 \pm 5.50\end{array}$ & $\begin{array}{l}92(62-100) \\
60(17-93)\end{array}$ & $\begin{array}{c}92(62-100) \\
0(0-54)\end{array}$ & CN3 (12) \\
\hline RiZ & $\begin{array}{l}\text { Apr } 2013^{b} \\
\text { May } 2013 \\
\text { May 2013 } \\
\text { May 2013 } \\
\text { May 2013 } \\
\text { May 2013 } \\
\text { May 2013 }\end{array}$ & $\begin{array}{c}\text { Adult } \\
\text { Adult } \\
\text { Juvenile }(12.32) \\
\text { Juvenile }(17.61) \\
\text { Juvenile }(22.76) \\
\text { Juvenile }(29.23) \\
\text { Juvenile }(36.87)\end{array}$ & $\begin{array}{r}3 \\
20 \\
10 \\
10 \\
10 \\
10 \\
10\end{array}$ & $\begin{aligned} 7.06 \times 10^{3} & \pm 1.75 \times 10^{3} \\
32.27 & \pm 32.27 \\
292.15 & \pm 158.65 \\
417.30 & \pm 198.46 \\
807.26 & \pm 374.41 \\
162.00 & \pm 45.30 \\
552.15 & \pm 119.88\end{aligned}$ & $\begin{aligned} 100 & (31-100) \\
5 & (0-27) \\
90 & (66-100) \\
100 & (66-100) \\
90 & (66-100) \\
100 & (66-100) \\
90 & (66-100)\end{aligned}$ & $\begin{array}{c}100(31-100) \\
5(0-27) \\
90(54-99) \\
70(35-92) \\
30(8-65) \\
50(20-80) \\
60(27-86)\end{array}$ & $\begin{array}{l}\text { CN3 (3) } \\
\text { CN3 (1) } \\
\text { CN3 (4) } \\
\text { CN3 (1) } \\
\text { CN3 (2) } \\
\text { CN3 (3) } \\
\text { CN3 }(4)\end{array}$ \\
\hline RongC & Jun 2013 & Adult & 10 & 0 & $0(0-34)$ & $0(0-34)$ & \\
\hline
\end{tabular}

Among 48 virus variants identified from previous studies, 23 (numbered as JPType1 to JPType23) isolated from Japan (Shimahara et al. 2012), 1 identified in China, 2 (numbered as KRType1 and KRType2) in South Korea, and the other 22 virus variants (numbered as AE1 to AE22) were identified from China (AE 8), USA (AE4 and AE19), Japan (AE9), Ireland (AE13), New Zealand (AE18), Australia (AE20) and France (the other 15 virus variants) (Table S1).

\section{Phylogeny of OsHV-1 virus variants}

To estimate the genetic relationship between OsHV-1 virus variants identified in this study and those reported in previous studies, a phylogenetic tree of these virus variants was constructed using the maximum parsimony (MP) method. All the sequences were trimmed from 2 ends to give them equal lengths. Finally, the aligned sequences resulted in a matrix of 614 characters (Fig. S1 in the Supplement). But after being coded by GapCoder, a final data matrix of 642 characters was created, of which 30 were potentially parsimony informative. We obtained $8835 \mathrm{MP}$ trees with 80 steps and recognized 2 major groups in all MP trees (Fig. 4). One group consisted of 33 virus variants (including the variant $\mu$ Var) that were identified from 6 countries (France, Ireland, Australia, New Zealand, Japan and South Korea). The other group was composed of remaining 20 virus variants (including the OsHV-1 reference virus type and AVNV) identified from 5 countries (France, the USA, Mexico, Japan and China). Virus variants identified in this study were allocated to a separate subclade.

\section{DISCUSSION}

The clinical signs and histological observations in infected Scapharca broughtonii broodstocks allow investigating abnormalities. The viral particles demonstrated by TEM in this study resemble those previously described from oysters in other countries in morphology (Hine et al. 1992, Renault et al. 1994b, Hine \& Thorne 1997, Burge \& Friedman 2012), but they were bigger in size than those reported previously (Hine et al. 1998, Renault et al. 1994b). Further evidence by qPCR revealed extremely high viral DNA loads in samples collected in 4 cases of mass mortalities $(n=75)$, which indicated the association between the detection of OsHV-1 DNA and $S$. 


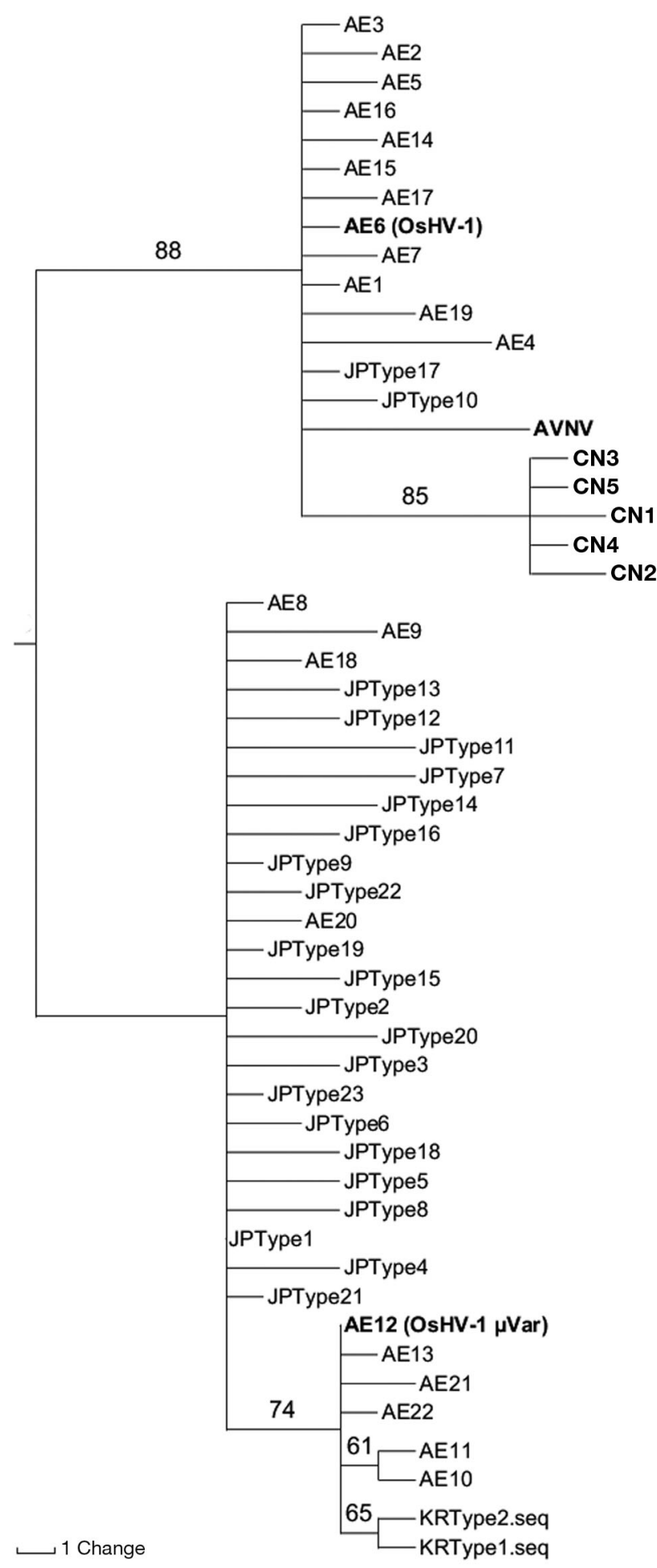

Fig. 4. Strict consensus tree from phylogenetic analyses for the virus variants of OsHV-1 using the maximum parsimony analysis. Numbers above the branches are the parsimony bootstrap support value $>50 \%$. CN: virus variants detected in this study. Virus variants identified in Japan (JPType), in South Korea (KRType), in China (AVNV) and in the other countries (AE) (see Table S1 in the Supplement) broughtonii loss. Additionally, significantly higher prevalence of OsHV-1 DNA was also found by both qPCR and nPCR among the stocks showing mortalities than among apparently healthy stocks. OsHV-1 infection in $S$. broughtonii has not been reported previously. We describe herein for the first time OsHV-1 infection of $S$. broughtonii associated with mass mortality in several commercial hatcheries in China. To our knowledge, this is also the first report of OsHV-1 infection of bivalve broodstocks associated with mass mortalities at lower temperatures.

In comparison to vertebrate herpesvirus, which have a limited number of hosts (Davison 2002), OsHV-1 is capable of infecting a variety of bivalve species belonging to different genera (Hine et al. 1992, Arzul et al. 2001, Renault et al. 2001, Bateman et al. 2012, Ren et al. 2013). Mortalities associated with the OsHV-1 are usually found in larvae and juveniles of susceptible bivalve species (Renault et al. 1995). However, inconsistent with previous studies, the mass mortalities associated with OsHV-1 infection in our study were found in the broodstocks of $S$. broughtonii. Notably, OsHV-1 infection of Chlamys farreri associated with mass mortalities was also found in adult individuals in China (Wang et al. 2002). These results may indicate that the OsHV-1 virus variants found in China exhibit different host stage preference compared with those found in the other countries. Further studies should be conducted to determine the underlying reasons for the different life stages susceptible to OsHV-1 variants found in China and in the other countries. It could result from the strain differentiation of OsHV-1, the interaction of the virus and host in a particular environment, the susceptibility of the host, or from other unknown causes (Vásquez-Yeomans et al. 2010).

Abnormal mortalities of a host caused by an infectious agent have always been associated with complex environmental factors. In the case of OsHV-1 infection, seawater temperature appears to be one of the most important potential factors influencing the incidence and outcome of OsHV-1 infection. High temperatures may enhance the expression of OsHV1 and thus increase the mortalities associated with the infection (Le Deuff et al. 1996, Petton et al. 2013). In this study, mass mortalities of $S$. broughtonii broodstocks were only observed when the water temperatures had increased to $18^{\circ} \mathrm{C}$. On the other hand, no abnormal mortality was observed in juveniles of $S$. broughtonii cultivated in lower temperatures, which carried DNA of the same OsHV-1 variant (CN3). These results highlighted the importance of water temperature as a potential factor influencing 
OsHV-1 infection. Although the losses reported here were inevitably associated with elevated seawater temperature in the hatcheries, the temperature threshold was lower than those $\left(23-25^{\circ} \mathrm{C}\right)$ previously associated with mass mortalities of $C$. farreri cultivated in the open sea in the 1990s in China (Wang et al. 2002).

Sauvage et al. (2009) reported that an average number of viral copies up to $10^{4} \mathrm{mg}^{-1}$ of tissue could be interpreted as evidence of viral infection leading to mass mortality. Furthermore, if the average number of viral copies is less than $1 \times 10^{3} \mathrm{mg}^{-1}$ of tissue, this should not be interpreted as an infective status associated with mortality (Pepin et al. 2008). In the present study, viral DNA loads up to or about $10^{4}$ copies $\mathrm{mg}^{-1}$ of tissue were detected in 4 batches of samples $(\mathrm{n}=75)$ associated with mass mortalities, while the viral DNA loads in the other 2 batches of samples $(n=19)$ associated with mortalities were far less than the threshold ( $10^{4}$ copies $\mathrm{mg}^{-1}$ of tissue). These results suggested that apart from OsHV-1 infection other factors also played a role in the onset of mortalities of blood clams in these cases.

Sequencing of 84 out of 133 positive samples generated 5 virus variants of OsHV-1, which allocated into a single subclade. Among the 5 virus variants identified in this study and 48 identified in previous studies, no shared virus variant was found between different countries. In contrast, shared virus variants have been detected between different EU countries (Dundon et al. 2011, Lynch et al. 2012, Roque et al. 2012), which may be due to frequent trade of bivalves in these countries (Pawiro 2010). In this study, 5 virus variants were found in $S$. broughtonii broodstocks both introduced from South Korea and indigenous to China. These variants have also been detected in the other 4 bivalve species (C. farreri, Patinopecten yessoensis, Ruditapes philippinarum and Crassostrea hongkongensis) cultivated in the other regions of China recently (Bai et al. 2015) but have not been detected in South Korea (Hwang et al. 2013). Since only C. gigas with small sample sizes were tested in South Korea, it is still difficult to deduce whether these variants were introduced from South Korea or not.

There were 32 samples in which OsHV-1 DNA was not detected by nPCR assay but proved to be positive by qPCR assay. The detection failure for 19 of them by nPCR might be explained by small amounts of OsHV-1 DNA contained in these samples, while the other 13 samples containing more than 100 GEs quantified by qPCR also tested negative by nPCR. Amplification failure of OsHV-1 DNA of the same genome region targeted by $\mathrm{nPCR}$ was also reported by Friedman et al. (2005). Since this region has been proved to demonstrate a high degree of polymorphism, we suggest that nucleotide variation in $\mathrm{nPCR}$ primer-binding sites may be responsible for the amplification failure of some samples with high viral DNA loads. These results indicated that qPCR assay is more sensitive than nPCR assay. Additionally, since nPCR assay is not able to provide quantitative information on the infection intensity of OsHV-1, which is a predictor of lethal infection, qPCR should be employed for routine epidemiologial studies of OsHV-1 infection (Renault et al. 2014).

In conclusion, this study reported findings from 2012 and 2013 for analysis of $S$. broughtonii, which correspond to the first detection of OsHV-1 infection in $S$. broughtonii and were associated with high mortalities in several locations. Our survey also confirmed the diversity of the OsHV-1 genome with the description of 5 newly reported variants associated with the mass mortalities of $S$. broughtonii in China. Since OsHV-1 infection has been detected in bivalves belonging to different genera, it is of importance to conduct surveillance and monitoring programs for OsHV-1 of other sympatric mollusk species in OsHV-1-infected regions. Furthermore, due to the increasing interest in the $S$. broughtonii farming industry, strict quarantine measures should be taken to minimize the risk of introduction of infectious agents along with the introduction of broodstocks.

Acknowledgements. We thank Jing Qian and Junyang Xia for collecting the samples. We are very grateful to Mike Hine and 3 anonymous reviewers who have provided extremely thorough and thoughtful comments on the draft of the manuscript. This research was supported by grants from the China Agriculture Research System (Project No. CARS48), the National Natural Science Foundation of China under Grant No. 31502208, the Scientific and Technological Innovation Project financially supported by Qingdao National Laboratory for Marine Science and Technology (No. 2015ASKJ01), the special foundation under the Construction Programme for 'Taishan Scholarship' of Shandong Province of China and the National Marine Public Welfare Research Project (No. 201205023).

\section{LITERATURE CITED}

An HY, Park JY (2005) Ten new highly polymorphic microsatellite loci in the blood clam, Scapharca broughtonii. Mol Ecol Notes 5:896-898

Arzul I, Nicolas JL, Davison AJ, Renault T (2001) French scallops: a new host for ostreid herpesvirus-1. Virology 290:342-349

Arzul I, Renault T, Thebault A, Gerard A (2002) Detection of oyster herpesvirus DNA and proteins in asymptomatic 
Crassostrea gigas adults. Virus Res 84:151-160

Bai C, Wang CM, Xia JY, Sun HL, Zhang S, Huang J (2015) Emerging and endemic types of Ostreid herpesvirus 1 were detected in bivalves in China. J Invertebr Pathol 124:98-106

Bateman KS, White P, Longshaw M (2012) Virus-like particles associated with mortalities of the Manila clam Ruditapes philippinarum in England. Dis Aquat Org 99: 163-167

> Burge CA, Friedman CS (2012) Quantifying Ostreid herpesvirus (OsHV-1) genome copies and expression during transmission. Microb Ecol 63:596-604

> Chang PH, Kuo ST, Lai SH, Yang HS, Ting YY, Hsu CL, Chen HC (2005) Herpes-like virus infection causing mortality of cultured abalone Haliotis diversicolor supertexta in Taiwan. Dis Aquat Org 65:23-27

> Davison AJ (2002) Evolution of the herpesviruses. Vet Microbiol 86:69-88

> Davison AJ, Trus BL, Cheng N, Steven AC and others (2005) A novel class of herpesvirus with bivalve hosts. J Gen Virol 86:41-53

> Davison AJ, Eberle R, Ehlers B, Hayward GS and others (2009) The order Herpesvirales. Arch Virol 154:171-177

> Dundon WG, Arzul I, Omnes E, Robert M and others (2011) Detection of Type 1 Ostreid Herpes variant (OsHV-1 $\mu$ var) with no associated mortality in French-origin Pacific cupped oyster Crassostrea gigas farmed in Italy. Aquaculture 314:49-52

Farley CA, Banfield WG, Kasnic G Jr, Foster WS (1972) Oyster herpes-type virus. Science 178:759-760

Friedman CS, Estes RM, Stokes NA, Burge CA and others (2005) Herpes virus in juvenile Pacific oysters Crassostrea gigas from Tomales Bay, California, coincides with summer mortality episodes. Dis Aquat Org 63:33-41

Hall T (1999) BioEdit: a user-friendly biological sequence alignment editor and analysis program for Windows 95/98/NT. Nucl Acids Symp Ser 41:95-98

> Hine PM, Thorne T (1997) Replication of herpes-like viruses in haemocytes of adult flat oysters Ostrea angasi: an ultrastructural study. Dis Aquat Org 29:189-196

> Hine PM, Wesney B, Hay BE (1992) Herpesviruses associated with mortalities among hatchery-reared larval Pacific oysters Crassostrea-gigas. Dis Aquat Org 12:135-142

Hine PM, Wesnay B, Basant P (1998) Replication of a herpeslike virus in larvae of the flat oyster Tiostrea chilensis at ambient temperatures. Dis Aquat Org 32:161-171

Hwang JY, Park JJ, Yu HJ, Hur YB, Arzul I, Couraleau Y, Park MA (2013) Ostreid herpesvirus 1 infection in farmed Pacific oyster larvae, Crassostrea gigas (Thunberg) in Korea. J Fish Dis 36:969-972

Jee BY, Lee SJ, Cho MY, Lee SJ and others (2013) Detection of Ostreid herpesvirus 1 from adult Pacific oysters Crassostrea gigas cultured in Korea. Fish Aquat Sci 16: 131-135

Katoh K, Standley DM (2013) MAFFT Multiple sequence alignment software Version 7: improvements in performance and usability. Mol Biol Evol 30:772-780

Katoh K, Misawa K, Kuma K, Miyata T (2002) MAFFT: a novel method for rapid multiple sequence alignment based on fast Fourier transform. Nucleic Acids Res 30: 3059-3066

Le Deuff RM, Renault T, Gérard A (1996) Effects of temperature on herpes-like virus detection among hatcheryreared larval Pacific oyster Crassostrea gigas. Dis Aquat Org 24:149-157
Le Deuff RM, Renault T (1999) Purification and partial genome characterization of a herpes-like virus infecting the Japanese oyster, Crassostrea gigas. J Gen Virol 80: 1317-1322

Li K (1996) Analysis of the cause and preventive measures of disease occurrence of Scapharca broughtonii. Fish Sci 15:36-37

Liang C, Yang A, Liu Z, Zhou L, Wu B (2011) Morphological variations and discriminant analysis of different geographical populations of Scapharca broughtonii Schrenck. Mark Sci 35:108-113

> Lynch SA, Carlsson J, Reilly AO, Cotter E, Culloty SC (2012) A previously undescribed ostreid herpesvirus 1 (OsHV1) genotype detected in the Pacific oyster, Crassostrea gigas, in Ireland. Parasitology 139:1526-1532

Martenot C, Oden E, Travaillé E, Malas JP, Houssin M (2010) Comparison of two real-time PCR methods for detection of ostreid herpesvirus 1 in the Pacific oyster Crassostrea gigas. J Virol Methods 170:86-89

Minson A, Davison A, Eberle R, Desrosiers R and others (2000) Family Herpesviridae. In: van Regenmortel MHV, Fauquet CM, Bishop DHL, Carstens EB and others (eds) Virus taxonomy. Seventh Report of the International Committee on Taxonomy of Viruses. Academic Press, San Diego, CA, p 203-225

Pawiro S (2010) Bivalves: global production and trade trends. In: Rees G, Pond K, Bartram J (eds) Safe management of shellfish and harvest waters. IWA Publishing, London, p 11-19

$>$ Pepin JF, Riou A, Renault T (2008) Rapid and sensitive detection of ostreid herpesvirus 1 in oyster samples by real-time PCR. J Virol Methods 149:269-276

> Petton B, Pernet F, Robert R, Boudry P (2013) Temperature influence on pathogen transmission and subsequent mortalities in juvenile Pacific oysters Crassostrea gigas. Aquacult Environ Interact 3:257-273

> Ren W, Chen HX, Renault T, Cai YY, Bai CM, Wang CM, Huang J (2013) Complete genome sequence of acute viral necrosis virus associated with massive mortality outbreaks in the Chinese scallop, Chlamys farreri. Virol J 10:110

Renault T, Arzul I (2001) Herpes-like virus infections in hatchery-reared bivalve larvae in Europe: specific viral DNA detection by PCR. J Fish Dis 24:161-167

Renault T, Cochennec N, Le Deuff RM, Chollet B (1994a) Herpes-like virus infecting Japanese oyster (Crassostrea gigas) spat. Bull Eur Assoc Fish Pathol 14:64-66

Renault T, Le Deuff RM, Cochennec N, Maffart P (1994b) Herpesviruses associated with mortalities among Pacific oyster, Crassostrea gigas, in France-comparative study. Rev Méd Vét 145:735-742

Renault T, Le Deuff RM, Cochennec N, Chollet B, Maffart P (1995) Herpes-like viruses associated with high mortality levels in larvae and spat of Pacific oysters, Crassostrea gigas: a comparative study, the thermal effects on virus detection in hatchery-reared larvae, reproduction of the disease in axenic larvae. Vet Res 26:539-543

> Renault T, Le Deuff RM, Chollet B, Cochennec N, Gerard A (2000) Concomitant herpes-like virus infections in hatchery-reared larvae and nursery-cultured spat Crassostrea gigas and Ostrea edulis. Dis Aquat Org 42:173-183

> Renault T, Lipart C, Arzul I (2001) A herpes-like virus infects a non-ostreid bivalve species: virus replication in Ruditapes philippinarum larvae. Dis Aquat Org 45:1-7

Renault T, Moreau P, Faury N, Pepin JF, Segarra A, Webb S (2012) Analysis of clinical ostreid herpesvirus 1 (Malaco- 
herpesviridae) specimens by sequencing amplified fragments from three virus genome areas. J Virol 86: 5942-5947

Renault T, Bouquet AL, Maurice JT, Lupo C, Blachier P (2014) Ostreid herpesvirus 1 infection among Pacific oyster (Crassostrea gigas) spat: relevance of water temperature to virus replication and circulation prior to the onset of mortality. Appl Environ Microbiol 80:5419-5426

Roque A, Carrasco N, Andree KB, Lacuesta B and others (2012) First report of OsHV-1 microvar in Pacific oyster (Crassostrea gigas) cultured in Spain. Aquaculture 324-325:303-306

Rozas J, Sanchez-DelBarrio JC, Messeguer X, Rozas R (2003) DnaSP, DNA polymorphism analyses by the coalescent and other methods. Bioinformatics 19:2496-2497

Sauvage C, Pepin JF, Lapegue S, Boudry P, Renault T (2009) Ostreid herpesvirus 1 infection in families of the Pacific oyster, Crassostrea gigas, during a summer mortality outbreak: differences in viral DNA detection and quantification using real-time PCR. Virus Res 142:181-187

Shimahara Y, Kurita J, Kiryu I, Nishioka T and others (2012) Surveillance of type 1 ostreid herpesvirus (OsHV-1) variants in Japan. Fish Pathol 47:129-136

Simmons MP, Ochoterena H (2000) Gaps as characters in sequence-based phylogenetic analyses. Syst Biol 49: 369-381

Song WB, Wang CM, Wang XH, Li Y, Li J (2001) New research progress on massive mortality of cultured scallop, Chlamys farreri. Mark Sci 25:23-26

Sugiura D, Katayama S, Sasa S, Sasaki K (2014) Age and

Editorial responsibility: Mike Hine,

Fouras, France growth of the ark shell Scapharca broughtonii (Bivalvia, Arcidae) in Japanese waters. J Shellfish Res 33:315-324

- Tan J, Lancaster M, Hyatt A, van Driel R, Wong F, Wamer S (2008) Purification of a herpes-like virus from abalone (Haliotis spp.) with ganglioneuritis and detection by transmission electron microscopy. J Virol Methods 149: 338-341

Tang Q, Qiu X, Wang J, Guo X, Yang A (1994) Resource enhancement of arkshell (Scapharca (Anadara) broughtonii) in Shandong offshore waters. Chin J Appl Ecol 5: 396-402

> Vásquez-Yeomans R, García-Ortega M, Cáceres-Martínez J (2010) Gill erosion and herpesvirus in Crassostrea gigas cultured in Baja California, Mexico. Dis Aquat Org 89: 137-144

Wang Q, Li W (1986) Study of the artificial breeding of blood clam, Scapharca broughtonii Schrenck. Chinese J Zool 1986:1-3

Wang Z, Sui X (1996) Investigation of the cause of Scapharca broughtonii mortality through ecological simulation. Fish Sci 15:31-33

Wang C, Wang X, Song X, Huang J, Song W (2002) Purification and ultrastructure of a spherical virus in cultured scallop, Chlamys farreri. J Fish Chin 26:180-184

> Young ND, Healy J (2003) GapCoder automates the use of indel characters in phylogenetic analysis. BMC Bioinformatics 4:6

Zhang Q, Wang S (1994) Factors related to the death of Scapharca broughtonii during raft rearing and its prevention methods. Mark Sci 1994:13-15

Submitted: November 3, 2014; Accepted: December 3, 2015 Proofs received from author(s): January 30, 2016 